\title{
Battle looms over future of Science Museum
}

London. A sharp conflict has broken out over the future plans for Britain's Science Museum. In one corner are traditional historians of science and technology, who want to see the museum preserved primarily as a national store and display case of historical artefacts. In the other are those who argue that more of the funds devoted to these activities should be diverted towards encouraging greater public understanding of contemporary science.

The trigger for the conflict has been the publication last month by the museum's director, Neil Cossons, of a new development plan. These include an increase in capital investment - for example in new galleries and other facilities designed to encourage greater public access to the museum - but also a reduction of 25 per cent in the number of curators.

Cossons defends this shift in the museum's priorities as reflecting the changing environment-in which the museum operates. In particular, he says, it is in line with the government's desire to see greater effort being put into the dissemination of information about modern scientific and technological achievements.

The Science Museum has, for example, already been identified in the recent white paper on science as the site of a major government-sponsored exhibition on contemporary science to be held in the year 2001, celebrating both the beginning of the new millennium and the Great Exhibition of 1851.

But such moves are being viewed with

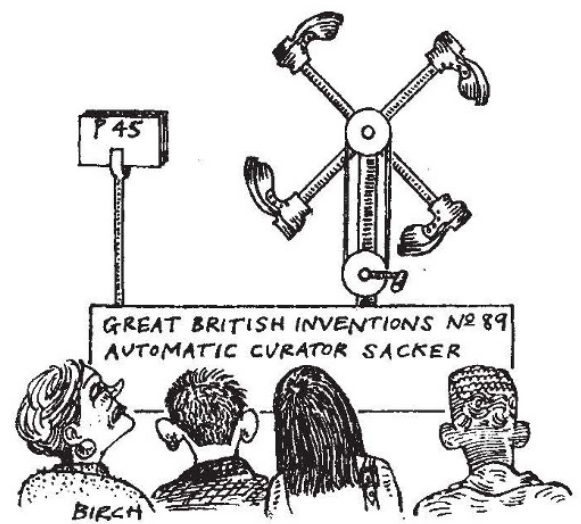

concern by many historians of science and technology, who fear that job reductions among curators will mean less effort being placed on the preservation and interpretation of historical artefacts, and that the museum's role as a custodian of these is in danger of becoming sacrificed to the shortterm priorities of government and industry.

"There is a balance to be struck between these two objectives, and some of us fear that the pendulum is swinging too far", says Geoffrey Cantor, professor of the history of science at the University of Leeds, and president of the British Society for the History of Science.

Last week, the society issued a statement criticizing, for example, the removal of a historical display of electricity and magnetism - including apparatus belonging to the nineteenth century physicist Michael Faraday - to make room for a celebration of modern medicine.

But John Durant, who holds a joint appointment as assistant director of the museum and professor of the public understanding of science at nearby Imperial College, and is widely seen as one of the architects of the proposed changes, justifies the shift in direction as matching the government's published ambitions in encouraging the greater public understanding of contemporary science.

"The challenge is to rethink the museum's historic mission in ways that are relevant to the rapidly changing circumstances of science and technology in the 1990s", said Durant, writing in a recent issue of Museums Journal.

Voluntary redundancies have already

been requested from existing staff, and Cossons says he hopes that much of the reduction he is looking for will be achieved in this way. But he does not rule out the possibility that some staff will have to leave.

Any such involuntary cuts are being strongly resisted by the various unions representing the staff of the museum, in particular the Institute of Professional Managers and Specialists, to which most of the curators belong.

The unions are already balloting their members on strike action. And in a joint letter to the Museums Journal the staff representatives of five different unions at the museum dispute that the cuts are needed to meet the changes outlined by Durant in his article. "At a time when the importance of producing effective displays which enhance the public's understanding of science and technology has never been greater, the Science Museum intends to make redundant the very staff who have the knowledge and experience to accomplish this difficult task", say the unions.

David Dickson

\section{Celltech announces public offering}

London. Celltech, Britain's oldest biopharmaceuticals start-up company, has announced plans to raise more than $\$ 30$ million by offering shares to the public through the London Stock Exchange. The new funds are to be used to finance existing and future development programmes and research projects.

Recent changes to the rules governing Stock Exchange listings for biotechnology companies in the United Kingdom have created the opportunity for a number of companies to meet their needs for funds by selling shares to the public.

"A Stock Exchange listing will enable us to raise finance to fund our existing and future projects," says Celltech's chief executive, Peter Fellner. "It will be our first such fund-raising since 1987 and will help fulfil our objective of developing into a profitable pharmaceutical company towards the end of this decade."

Indeed, Celltech has been able to fund its progress in recent years through deals with established pharmaceutical companies such as American Cyanamid, Bayer and Schering-Plough.

Most recently, Celltech signed a manufacturing and investment agreement with Hoffmann-La Roche which is expected to result in sales of up to $£ 30$ million in the next four years, and involves the Swiss company investing $£ 5$ million in Celltech.

Industry sources suggest that the Celltech Group is unlikely to make profits until the middle of the second half of the decade, although one of its two main businesses is already in the black. Celltech Biologics, which provides contract manufacturing services to the pharmaceutical industry, including monoclonal antibodies, has been consistently profitable, and sales in 1992 were $£ 12.9$ million.

While Celltech's avowed intention is to become a fully integrated pharmaceutical company, many of its frontline products are being developed in close collaboration with other pharmaceutical companies. The most advanced product involving Celltech is a mouse-derived anti-tumour necrosis factor antibody belonging to Bayer which is in phase III clinical trials for septic shock.

Bayer is also interested in Celltech's novel anti-tumour necrosis factor antibody, CDP571, which is in phase II trials to treat septic shock and rheumatoid arthritis and also a phase I trial for inflammatory bowel disease.

American Cyanamid is linked with Celltech's next most advanced product, a calicheamicin-antibody conjugate, which is in phase I trials against ovarian cancer. Similar calicheamicin-antibody conjugates are in preclinical trials against acute myeloid leukaemia and colorectal cancer and also involve American Cyanamid, the discoverer of the toxic cell killer which is guided to the cancer cells by the antibody.

One of the main reasons for the public flotation, seen by many biotechnology companies as a rite of passage, is that Celltech is keen that its earliest investors (the company was founded in 1980) should see some return on their investment. Mike Ward 